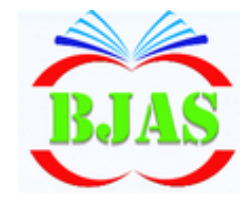

ISSN $1814-5868$
Available online at http://bjas.bajas.edu.iq

https://doi.org/10.37077/25200860.2020.33.1.07

College of Agriculture, University of Basrah
Basrah Journal

of Agricultural

Sciences

E-ISSN: 2520-0860

\title{
Single Nucleotide Polymorphisms in the Promoter of CYP19 Gene in Cattle Bred in Iraq
}

\author{
Salah H. Faraj ${ }^{1 *}$, Asaad Y. Ayied ${ }^{2}$ \& Khalaf A. H. Al-Rishdy ${ }^{2}$ \\ 1 Department of Biology, College of Science, University of Misan, Iraq \\ 2 Department of Animal Production, College of Agriculture, University of Basrah, Iraq \\ *Corresponding author e-mail: salah81ss@uomisan.edu.iq
}

Received 19 September 2019; Accepted 21 December 2019; Available online 27 April 2020

\begin{abstract}
The present study was undertaken to characterize the genetic diversity of the aromatase cytochrome P450 (CYP19) gene in 34 cows (15 local, 14 Holstein, and 5 Crosses) in Iraq. The objectives of the present study are to detect SNPs (mutations) in promoter p1.1 of the CYP19 gene in cattle bred in Iraq using sequencing techniques. We identified five singlenucleotide polymorphisms (SNP) loci of the CYP19 gene that were detected, namely G933T, G994C, A1044G, A1062T, and C1468A. The results showed the presence of 3, 4, and 2 polymorphic sites leading to the construction of 4, 5, and 3 different haplotypes for Holstein, local, and crosses respectively. Haplotype diversity were $0.791,0.752$, and 0.700 respectively. While nucleotide diversity was $0.0017,0.0022$, and 0.0013 respectively. Besides, we carried out a phylogenetic analysis of these sequences to address the evolutionary relationship between the animal species. These fragments were assigned in the GenBank database under the accession numbers: LC490756, LC490757, LC491437, LC491438, LC491439, LC491588, and LC491589.

Keywords: CYP19 gene, Iraqi cattle, single nucleotide polymorphism, Genetic Diversity, Phylogenetic tree
\end{abstract}

\section{Introduction}

The tools of molecular genetics, which allow the detection of genes, have major effects on complex traits, such as reproductive performance. These tools can be used as selection criteria for reproductive traits for genetic improvement (Amitosh, 2018). A large number of genes affect the reproductive performance of cattle, one of them is CYP19. It is an important gene that is significantly associated with these important traits in cattle (El-Bayomi et al., 2018). CYP19 gene belongs to the cytochromes P450 genes. P450 genes are part of a multi-gene superfamily, which contains 27 distinct genetic families, ten of which are dedicated to mammals, one of which is the CYP19 gene (Jedrzejczak et al., 2011). In mammals, reproduction is mainly regulated by estrogen, which is synthesized in ovaries trough the androgen's aromatization (Kowalewska- Luczak, 2010). The CYP19 gene encodes the cytochrome P450 aromatase enzyme, aromatase P450 catalyzes the last step in the steroidogenesis which converts the androgens (C19) to estrogens (C18) (Damiani \& Damiani, 2007), which maps to band q2.6 on 
chromosomes 10 and has 11 exons in cattle (Aken et al., 2016). CYP19 utilizes different promoters in tissue-specific expression in the alternative splicing mechanism (Simpson \& Davis, 2001). Different promoter regions correspond to different 5'-UTR transcripts but the coding region is identical for all tissues (Kalbe et $a l ., 2000)$. The placental expression of the CYP19 gene is regulated by $\mathrm{P} 1.1$ promoter, and $A>G$ mutation has been detected in this region (Keskin et al., 2015). As well as two SNPs in the P1.1 region of the CYP19 gene was identified, the first mutation was a $\mathrm{G}>\mathrm{A}$ transition at position 1044 and the second one was an $A>G$ transition at position 1179 (Mohamadnejad-Sangdehi et al., 2015). Several single nucleotide polymorphisms (SNPs) studies in CYP19 gene have been reported in different livestock species and breeds as; Slovak Simmental cattle (Trakovická et al., 2015), Jersey cattle (Kowalewska-Luczak et al., 2013), Rathi cattle (Amitosh et al., 2017), the crossbred cows in Egypt (Saber et al., 2017), Gyr dairy cows (Vega et al., 2018).

This study aimed at determining single nucleotide polymorphisms in the CYP19 gene using DNA sequencing methods and using bioinformatics tools to study this fragment in cattle bred in Iraq. As well as determining genetic diversity both within and between breed.

\section{Materials \& Methods}

\section{Animals and genomic DNA isolation}

This study included the use of 34 cows (15 local, 14 Holstein, and 5 Crosses). Blood

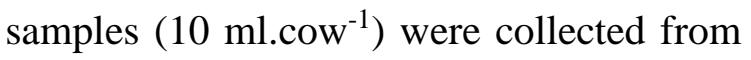
the jugular vein. Genomic DNA was extracted from whole blood using the gSYNCTM DNA Extraction Kit (Geneaid).
A fragment $(657 b p)$ in the P.1.1 promoter region of the CYP19 gene in cattle was amplified by using our designed primer $\mathrm{F}$ : 5 '-GGCAAGGGCCTCATATGGTT-3’

and $\mathrm{R}$ : 5'TGTCAGGGAATGTGAGGTGC-3`. The PCR amplifications were conducted in a 50 $\mu 1$ volume containing $6 \mu 1$ genomic DNA, $25 \mu \mathrm{l}$ of Master Mix, $4 \mu \mathrm{l}$ both primer, and $15 \mu \mathrm{l}$ free water. The amplification conditions were as follows: initial denaturation at $94 \mathrm{C}$ for $5 \mathrm{~min}$ followed by 35 cycles of denaturation at $94 \mathrm{C}$ for $1 \mathrm{~min}$, annealing at $56^{\circ} \mathrm{C}$ for $40 \mathrm{Sec}$, and extension at $72^{\circ} \mathrm{C}$ for $30 \mathrm{Sec}$., followed by the final extension at $72^{\circ} \mathrm{C}$ for $5 \mathrm{~min}$. The PCR product was detected by $2 \%$ agarose gel electrophoresis, stained with Ethedium bromide and visualized by ultraviolet light. For sequencing, the PCR product was sent to Yang ling Tianrun Aoka Biotechnology Company, China.

\section{Data Analysis}

The sequencing results of the CYP19 gene were compared with accession no. Z69241 at the NCBI by BioEdit 7.0 software (Hall, 1999). Haplotype diversity (HD) and nucleotide diversity $(\pi)$ were analyzed using DnaSP v5. 10 software (Librado \& Rozas, 2009). The haplotypes network was drawn using Network 5.0.0.0 software (Bandelt et al., 1999). The phylogenetic tree was drawn by using the MEGA $\mathrm{X}$ software (Kumar et al., 2018).

\section{Results}

The CYP19 haplotype sequences from cattle bred in Iraq have been assigned in the National Center for Biotechnology Information (NCBI), DNA Data Bank of Japan (DDBJ) and the European Nucleotide Archive (ENA) under the accession 
numbers (LC490756, LC490757, LC491437, LC491438, LC491439, LC491588, and LC491589).

\section{Genetic Diversity}

The total number of sequences $(\mathrm{N})$ and haplotypes $(\mathrm{H})$ were 34 and 7 respectively, resulted in 5 polymorphisms number $(\mathrm{NH})$ distributed to 4 local, 2 crosses and 3
Holstein (Table 1). Holstein revealed the highest value of haplotype diversity (HD) (0.791), followed by the local breed (0.752) and the cross cattle (0.700). On the contrary, local cattle recorded the highest nucleotide diversity $(\pi)$ followed byHolstein and cross cattle $(0.0022,0.0017$ and 0.0013 respectively).

Table (1): Genetic diversity of the CYP19 gene among different cattle breeds.

\begin{tabular}{cccccc}
\hline Breeds & $(\mathrm{N})$ & $(\mathrm{H})$ & $(\mathrm{NH})$ & $(\mathrm{HD})$ & $(\pi)$ \\
\hline Local & 15 & 5 & 4 & 0.752 & 0.0022 \\
\hline Crosses & 5 & 3 & 2 & 0.700 & 0.0013 \\
\hline Holstein & 14 & 4 & 3 & 0.791 & 0.0017 \\
\hline
\end{tabular}

N: Number of Sequences; H: Haplotype; NH: Number of polymorphic; HD: Haplotype Diversity; $\pi$ : Nucleotide Diversity

\section{Haplotype Network}

A total number of haplotypes of the CYP19 gene showed by different breeds were seven (Fig. 1). Three haplotypes (H-2, H-3, and $\mathrm{H}-4)$ found in all breeds while the remaining four are divided into two for the local breed (H-6 and H-7) and two for Holstein (H-1 and H-5). Each pair of haplotypes (H-2, H-5 or H-3, H-4) differs from each other with a nitrogen base (592bp). The haplotypes (H-2, H-3 or H-4, H-5) differ from each other with a nitrogen base (563bp). The branches represented $\mathrm{H}-$ 1 of Holstein cattle differed from H-3 by 28 and 89 bases. Whereas, the haplotypes H-6 and $\mathrm{H}-7$ represented the local cattle differed from $\mathrm{H}-2$ by 157 and 139 bases.

The results in fig. (2) observed the analysis of nucleotides in the P.1.1 promoter region of the CYP19 gene and they recorded five SNPs; guanine to thymine (G933T), guanine to cytosine (G994C), adenine to guanine (A1044G), adenine to thymine (A1062T) and cytosine to adenine (C1468A). All SNPs are recorded first time except (A1044G).

\section{Phylogenetic tree of CYP19 gene}

The evolutionary tree of the CYP19 gene showed that there were three main branches (Fig. 3). The first branch included the cattle bred in Iraq. The second branch included Holstein bred in Germany. While the third branch divided into two branches, the first branch was presented by the Australian cattle and the second Indian cattle. 
Faraj et al / Basrah J. Agric. Sci., Special 32 (1): 89-97, 2020

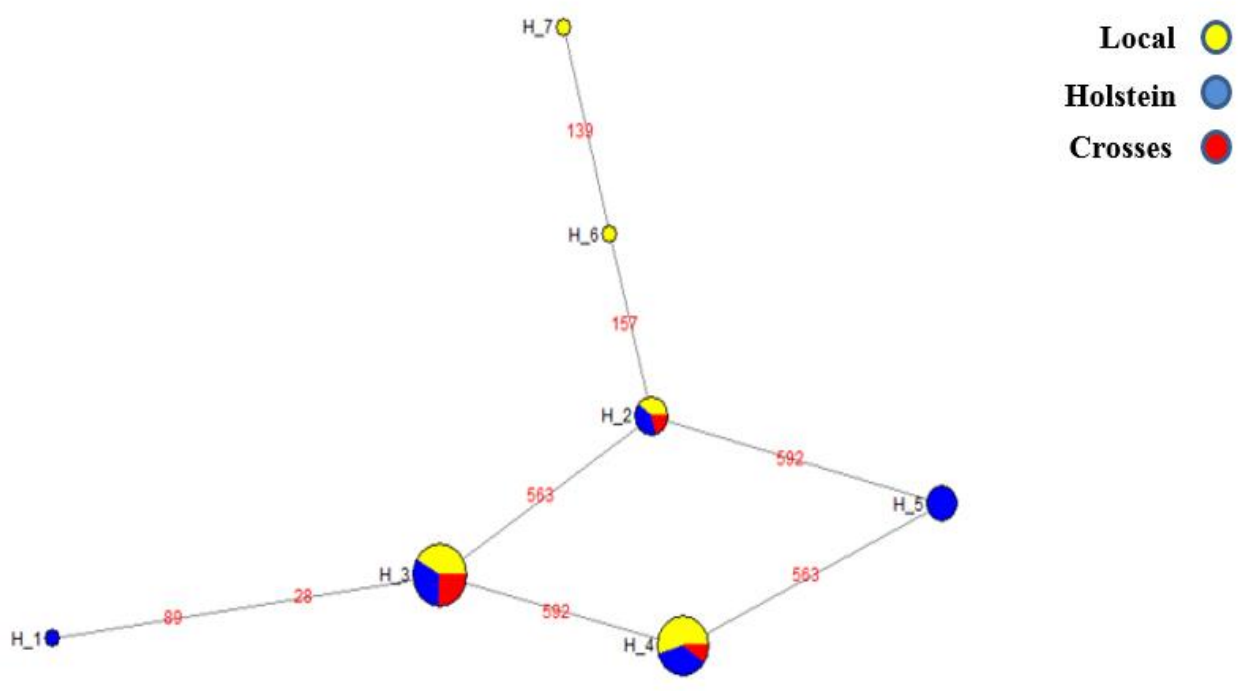

Fig. (1): Haplotype network of CYP19 gene among studied cattle.

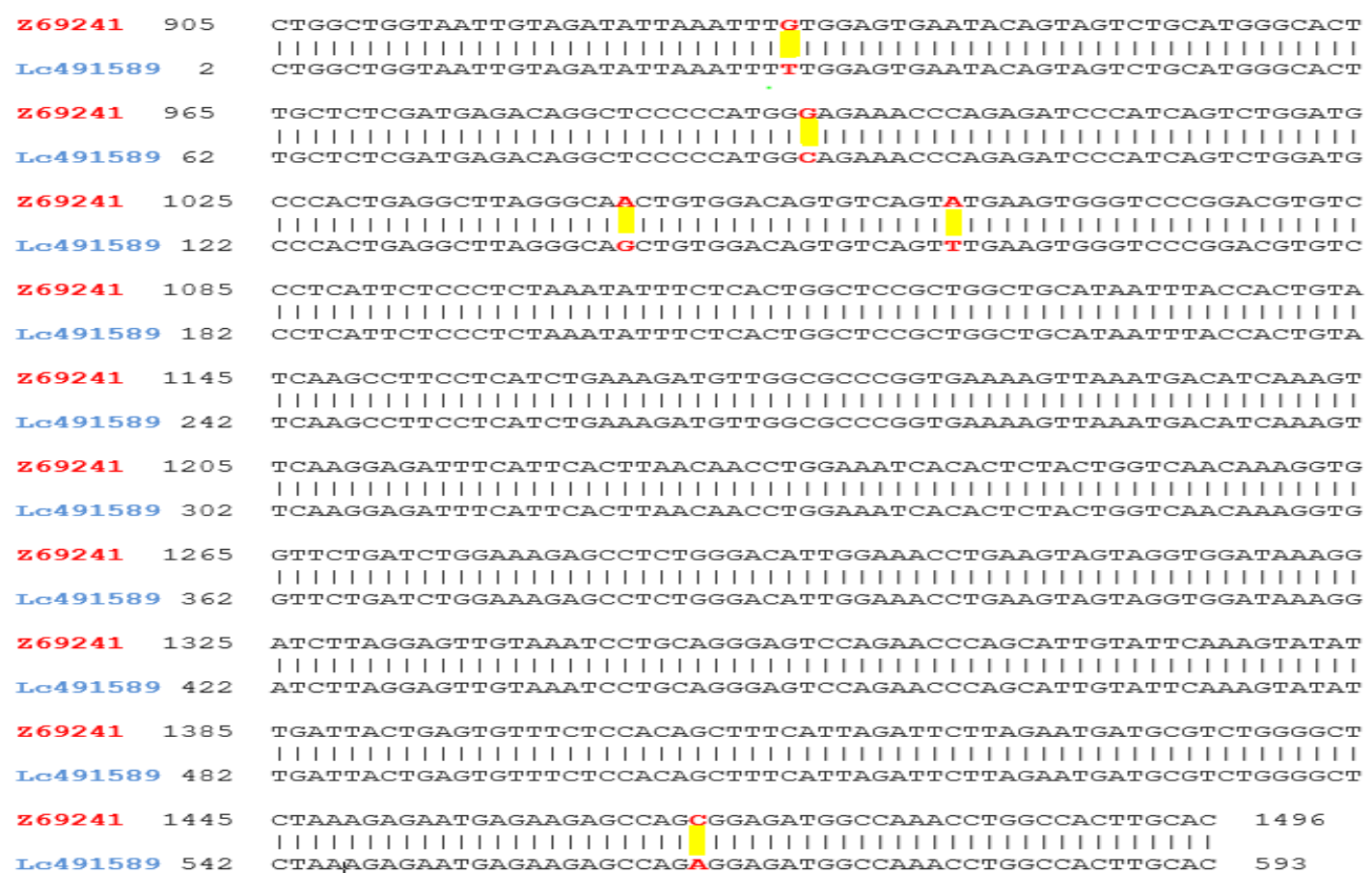

Fig. (2): Sequencing of the CYP19 gene in Iraqi Cattle (LC491589) vs. Reference Sequence (Z69241). 


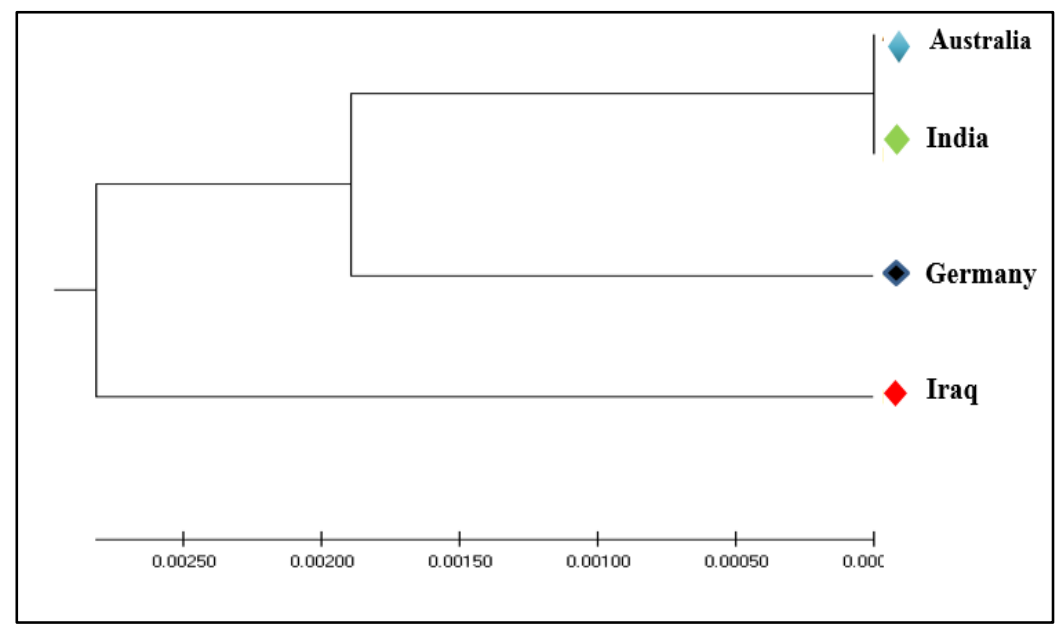

Fig. (3): The Phylogenetic tree of the CYP19 gene between some cattle bred in Iraq of different countries.

\section{Analysis of molecular variance AMOVA}

The results of the AMOVA of the CYP19 gene between and within cattle breeds showed that genetic variation between breeds was $0.30 \%$ and the variation within breeds was $99.70 \%$ from the total variance (Table 2). This finding illustrated by the fact that genetic variation within the breed is much greater than genetic variation among breeds.

Table (2): -Molecular contrast analysis of gene CYP19 with strains in the world.

\begin{tabular}{lcccc}
\hline Source of variation & df & Sum Squares & $\begin{array}{c}\text { Variance } \\
\text { Components }\end{array}$ & Variation \% \\
\hline Between breed & 2 & 1.650 & 0.0024 & 0.30 \\
\hline Within breed & 31 & 24.791 & 0.7997 & 99.70 \\
\hline Total & 33 & 26.441 & 0.8021 & \\
\hline
\end{tabular}

\section{Discussion}

Molecular markers could be powerful tools in the identification of SNPs and in revealing the current status of genetic diversity within and differentiation between livestock populations (Lenstra et al., 2012). There are a few numbers of studies carried on the CYP19 gene. The single-nucleotide polymorphisms can be used as a selection criterion for decreasing fertility problems. The present study was, therefore, aimed at determining both within and between breed genetic diversity of cattle bred in Iraq (local, Holstein, and crosses) using SNPs markers. Singlenucleotide polymorphisms (SNPs) markers are the most efficient molecular markers to evaluate genetic diversity, population differentiation, breed relationships, and 
determine parentage in animal populations (Yang et al., 2013). The genetic diversity of cattle has also recently been studied using SNPs markers in Ethiopia (Kukučková et al., 2018) and South Africa (Makina et al., 2016). Single-nucleotide polymorphisms (SNPs) in position 1044 obtained from the analysis of the present study are consistent with the previous studies carried out for promoter $\mathrm{p} 1.1$ of the CYP19 gene in cattle (Keskin et al., 2015; Mohamadnejad-Sangdehi et al., 2015; Zaborski et al., 2014). However, in the present study, other SNPs were found in the position 933, 994,1062 and 1468. These SNPs are novel to the studied Iraqi cattle. The reason behind that is that Iraq considers as an origin of sheep (Ayied \& Zaqeer, 2019), camel (Ayied et al., 2018) and cattle (Faraj et al., 2019; Owaid et al, 2019).

The partitioning of the genetic variation from an AMOVA revealed that $0.30 \%$ of the total genetic variation was between breeds. A similar pattern of variance partitioning was observed in similar studies (Edea et al., 2013; Ngono-Ema et al., 2014; Sanarana et al., 2016; Gororo et al., 2018), in which $90 \%$ or more of the variation is contained within breeds. In Ankole cattle breeds, Öner et al. (2019) reported within-population diversity to be $92.2 \%$.

\section{Conclusion}

Cattle bred in Iraq showed a high genetic diversity of the CYP19 gene. The tree of evolution has shown the presence of cattle bred in Iraq with a separate branch from other cattle breeds. Genetic variation within breed was greater than genetic variation among breeds. CYP19 gene of cattle bred in Iraq showed five mutations at the sites 933, 994, 1044, 1062 and 1468. Local cattle differ from Holstein cattle by two haplotypes (H1 and H5 for Holstein and $\mathrm{H} 6$ and $\mathrm{H} 7$ for local).
However, both share three haplotypes (H2, $\mathrm{H} 3$, and $\mathrm{H} 4$ ).

\section{Acknowledgments}

The authors are very grateful to the Molecular genetic laboratory staff, Animal Production Department, College of Agriculture, University of Basrah.

\section{Conflicts of interest}

The authors-declare-that they-have-noconflict of interests.

\section{Ethical approval}

All applicable institutional, national and international guidelines for the care and use of animals were followed.

\section{References}

Aken, B.L.; Achuthan, P.; Akanni, W.M.; Amode, R.; Bernsdorff, F.; Bhai, J.; Billis, K.; Carvalho-Silva, D.; Cummins, C.; Clapham, P et (2016). The ensemble gene annotation system. Database., 1-19. https://doi.org/10.1093\%2Fdatabase\%2Fba w093.

Amitosh, K. (2018). Molecular characterization of CYP19, FSHR and LHR genes and its association with reproductive traits in Indigenous cattle. Ph.D. Thesis. Coll. Vet. Anim. Sci., Univ. Rajasthan: 141pp. http://krishikosh.egranth.ac.in/handle/1/58100 55058

Amitosh, K.; Gahlot, G.C.; Joshi, R.; Ashraf, M. \& Ganguly, S. (2017). DNA polymorphism of the CYP19 (Aromatase) gene in Rathi cattle. J. Entomol. Zool. Stud.; 5(6): 1944-1946.

https://www.researchgate.net/publication/321 825089_DNA_polymorphism_of_Cyp19_Aro matase_gene_in_Rathi_cattle

Ayied, A.Y. \& Zaqeer, B.F. (2019). Relationship between ND5 genetic 
Faraj et al / Basrah J. Agric. Sci., Special 32 (1): 89-97, 2020

polymorphisms and milk production and the growth of lambs before weaning of Awassi sheep. $\quad$ IJSR, $\quad 8(1)$ : 810-814. https://www.ijsr.net/search_index_results_pap erid.php?id=ART20194226

Ayied, A.Y.; Al-Badran, A.I.; \& Al-Zaalan, A.R. (2018). Assessment of genetic diversity in Iraqi camel breeds using cytochrome $b$. JAAVS, $\quad 6(7)$ : 273-277. http://doi.org/10.17582/journal.aavs/2018/6.7. 273.277

Bandelt, H.J.; Forster, P. \& Rohl, A. (1999). Median-joining networks for inferring intraspecific phylogenies. Mol. Biol. Evol., 16(1): $37-48$. https://academic.oup.com/mbe/articleabstract/16/1/37/993192

Damiani, D. \& Damiani, D. (2007). Manejo farmacológico da baixa estatura: o papel dos inibidores da aromatase: Revisão. Jornal de Pediatria, $\quad$ 83(5): 172-177. https://doi.org/10.1590/S002175572007000700008

Edea, Z.; Dadi, H.; Kim, S.W.; Dessie, T.; Lee, T.; Kim, H.; Kim, J.J. \& Kim, K.S. (2013). Genetic diversity, population structure, and relationships in indigenous cattle populations of Ethiopia and Korean Hanwoo breeds using SNP markers. Front. Genet. 4(35): $1-9$. https://doi.org/10.3389/fgene.2013.00035

El-Bayomi, K.M.; Saleh, A.A.; Awad, A.; ElTarabany, M.S.; El-Qaliouby, H.S.; Afifi, A.; El-Komy, S.; Essawi, W.M.; Almadaly, E.A. \& El-Magd, M.A. (2018). Association of CYP19A1 gene polymorphisms with anoestrus in water buffaloes. Reprod. Fert. Develop., 30: 487- 497. https://doi.org/10.1071/RD16528

Faraj, S.H.; Ayied, A.S. \& Al-Rishdy, K.A.H. (2019) FSHR gene polymorphisms and protein structure changes of cattle bred in
Iraq. $\quad$ IJSTR, 8(11): 3325-3328. http://www.ijstr.org/research-paperpublishing.php?month=nov2019

Gororo, E.; Makuza, S.M.; Chatiza, F.P.; Chidzwondo, F. \& Sanyika, T.W. (2018). Genetic diversity in Zimbabwean Sanga cattle breeds using microsatellite markers. S. Afr. J. Anim. $\quad$ Sci., 48(1): 128-141. https://doi.org/10.4314/sajas.v48i1.15

Hall, T.A. (1999). BioEdit: a user-friendly biological sequence alignment editor and analysis program for Windows 95/98/ NT. Nucl. Acids Symp., 41: 95-98. https://bioedit.software.informer.com/

Jedrzejczak, M.; Grzesiak, W.; Szatkowska, I.; Dybus, A.; Muszyńska, M. \& Zaborski, D. (2011). Association between polymorphisms of CYP19, CYP21, and ER1 genes and milk production traits in Black and White cattle. Turk. J. Vet. Anim. Sci., 35(1): 41-49. https://www.researchgate.net/publication/2284 96295_Association_between_polymorphisms_of _CYP19_CYP21_and_ER1_genes_and_milk_produ ction_traits_in_Black-and-White_cattle

Kalbe, C.; Furbass, R.; Schwerin, M.\& Vanselow, J. (2000). Cis-acting elements regulating the placenta-specific promoter of the bovine Cyp19 gene. J. Mol. Endocrinal., 25: 265-273.

https://doi.org/10.1677/jme.0.0250265

Keskin, A.; Öner, Y.; Yilmazbaş-mecitoğlu, G.; Güner, B.; Karakaya, E.; Elmaci, C. \& Gümen, A. (2015). Distributions of CYP19, $E R \alpha$ and $P G R$ allele frequencies between fertile and subfertile holstein-friesian heifers. Kafkas. Univ. Vet. Fak. Derg., 21(6): 893898. https://doi.org/10.9775/kvfd.2013.8900

Kowalewska-Uczak, I. (2010). Polymorphism of the CYP19 gene and milk production traits of dairy cattle. Turk. J. Vet. Anim. Sci., 34(6): 493-496 . https://doi.org/10.3906/vet-0707-30 
Kowalewska-Luczak, I.; Michniewicz, E. \& Kulig, H. (2013). Effect of CYP19 SNPs on milk production traits of jersey cows. Acta Sci. Pol., Zootechnica, 12(1), 33-40. https://asp.zut.edu.pl/2013/12_1/asp-2013-12-1170.pdf

Kukučková, V.; Moravčíková, N.; Curik, I.; Simčič, M.; Mészáros, G. \& Kasarda, R. (2018). Genetic diversity of local cattle. Acta Bioch. Pol., 65(3): 421-424. https://doi.org/10.18388/abp.2017_2347

Kumar, S.; Stecher, G.; Li, M.; Knyaz, C. \& Tamura, K. (2018). MEGA X: Molecular Evolutionary Genetics Analysis, across computing platforms. Mol. Biol. Evol., 35: 1547-1549.

https://doi.org/10.1093/molbev/msy096

Lenstra, J.; Groeneveld, L.; Eding, H.; Kantanen, J.; Williams, J.; Taberlet, P.; Nicolazzi, E.; Sölkner, J.; Simianer, H. \& Ciani, E. (2012). Molecular tools and analytical approaches for the characterization of farm animal genetic diversity. Anim. Genet., 43: 483-502. https://doi.org/10.1111/j.1365-

2052.2011.02309.x

Librado, P. \& Rozas, J. (2009). DnaSP v5: a software for comprehensive analysis of DNA polymorphism data. Bioinformatics, 25(11): 1451-1452.

https://doi.org/10.1093/bioinformatics/btp187

Makina, S.O.; Whitacre, L.K.; Decker, J.E., Taylor, J.F.; MacNeil, M.D.; Scholtz, M.M.; Marle-Köster, E.; Muchadeyi, F.C.; Makgahlela, M.L. \& Maiwashe, A. (2016). Insight into the genetic composition of South African Sanga cattle using SNP data from cattle breeds worldwide. Genet. Sel. Evol. (Paris), $\quad 48 \quad$ (1): $\quad 88-94$. https://doi.org/10.1186/s12711-016-0266-1
Mohamadnejad-Sangdehi, F.; Rahimi-Mianji, G.; Safdari-Shahroudi, M.; Razavi-Sheshdeh, S.A. \& Gholami, M. (2015). Distribution of allele frequencies at 5'-flanking region of CYP19 and ER $\alpha$ genes between Iranian simmental and three indigenous cattle breeds. Iranian J. Appl. Anim. Sci., 5(2): 301-307. http://ijas.iaurasht.ac.ir/article_513309.html

Ngono-Ema, P.; Manjeli, Y.; Meutchieyié, F.; Keambou, C.; Wanjala, B.; Desta, A.; Ommeh, S.; Skilton, R. \& Djikeng, A. (2014). Genetic diversity of four Cameroonian indigenous cattle breeds using microsatellite markers. J. Livest. Sci., 5: 9-17.

Öner, Y.; Yı1maz, O.; Eriş, C.; Ata, N.; Ünal, C. \& Koncagül, S. (2019). Genetic diversity and population structure of Turkish native cattle breeds. S. Afr. J. Anim. Sci., 49(4): 628-635. http://doi.org/10.4314/sajas.v49i4.4

Owaid, J.M.; Ayied, A.Y. \& Ahmed, F.A. (2019). Genetic variation analysis of ATPase gene and its association with milk component in cattle. IJANS, 8(3): 55-60. https://www.iaset.us/journals/internationaljournals/international-journal-of-applied-andnatural-sciences

Saber, Y.H.; Seida, A.A.; Ragab, R.S.A.; Balabel, E.A.; Hanafi, E.M. \& Wahid M.A. (2017). Oxidant/antioxidant status and CYP19 gene polymorphism in crossbred cows in relation to ovarian inactivity. Global Vet. 18(1): 14-19. https://www.idosi.org/gv/gv18(1)17.htm

Sanarana, Y.; Visser, C.; Bosman, L.; Nephawe, K.; Maiwashe, A. \& Van MarleKöster, E. (2016). Genetic diversity in South African Nguni cattle ecotypes based on microsatellite markers. Trop. Anim. Health Prod., 48 , 379-385. https://doi.org/10.1007/s11250-015-0962-9 
Simpson, E.R. \& Davis, S.R. (2001). estrogen biosynthesis-some new perspectives. Endocrinology., $\quad 142$ : $\quad 4589-4594$. https://doi.org/10.1210/endo.142.11.8547

Trakovická, A.; Moravčíková, N.; Miluchová, M. \& Gábor, M. (2015). Analysis of CYP19 gene polymorphism as a factor affecting milk production of cattle. J. Microbiol. Biotechnol. Food Sci., 4(2): 111-113. https://doi.org/10.5513/JCEA01/19.4.2363

Vega, W.H.O.; Quirino, C.R.; BartholazziJunior, A.; Rua, M.A.S.; Serapiao, R.V. \& Oliveira, C.S. (2018). Variants in the CYP19A1 gene can affect in vitro embryo production traits in cattle. J. Assisted Reprod.
Minireview: Aromatase and the regulation of

Genet., 35(12):

2233-2241. https://doi.org/10.1007/s10815-018-1320-4

Yang, W.; Kang, X.; Yang, Q.; Lin, Y. \& Fang, M. (2013). Review on the development of genotyping methods for assessing farm animal diversity. J. Anim. Sci. Biotechnol., 4(2): 1-6. https://doi.org/10.1186\%2F20491891-4-2

Zaborski, D.; Grzesiak, W. \& Pilarczyk, R. (2014). Detection of difficult calving's in the Polish holstein-friesian black and white heifers. J. Appl. Anim. Res., 44(1): 42-53. https://doi.org/10.1080/09712119.2014.98729 3

\section{تعدد أشكال النيوكليوتيدات الفردية (SNPs) في منظم جين CYP19 في الأبقار المرباة في العرلق}

$$
\text { قسلاح حسن فرج واسعد يحيى عايد وخلف عبدالرزاق حسن }
$$

المستخلص أجريت الدراسة الحالية لوصف التنوع الجيني لجين اروماتيز السيتوكروم (CYP19) P450 في 34 بقرة (15)

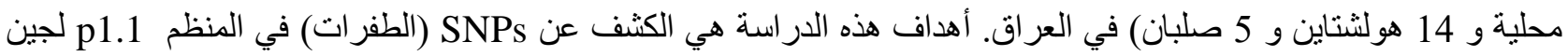
في الأبقار المرباة في العراق باستخدام تقنيات التسلسل. اكتشفت خمسة تشكلات متعددة للتشكلات أحادية النوكليوتيد

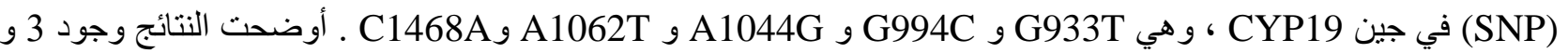
4 و 2 مناطق متعددة الأشكال مما أدى إلى بناء 4 و 5 و 3 أنماط احادية مختلفة لابقار الهولنتاين و المحلية و المضربة على التوالئ التي.

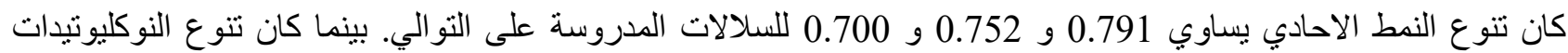
0.0017 و 0.0022 و 0.0013 على التو الي. إلى جانب ذلك ، اجري تحليل جيني للسلالات باستخدام هذه التسلسلات لحساب التساب

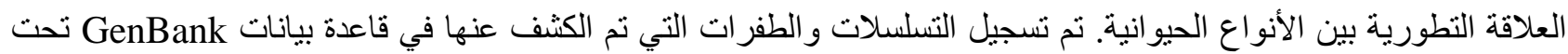

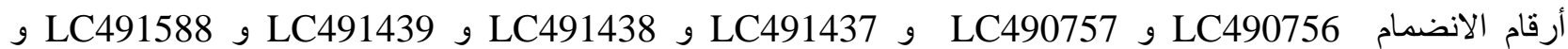

